\title{
Scoring the efficiency of Portuguese wine exports - an analysis recurring to Stochastic Frontier Models
}

\author{
Avaliando a eficiência das exportações portuguesas de vinho - uma análise com recurso a Modelos de \\ Fronteira Estocástica
}

\section{Paulo Reis Mourão ${ }^{1 *}$, Vítor Domingues Martinho²}

\author{
${ }^{1}$ Dept. Economics; University of Minho; Campus de Gualtar, 4710 - 057 Braga, Portugal. \\ ${ }^{2}$ Agricultural School; Polytechnic Institute of Viseu; Quinta da Alagoa - Estrada de Nelas, Ranhados, 3500 - 606 Viseu, Portugal. \\ *corresponding author: Tel.: +351253604510; e-mail: paulom@eeg.uminho.pt \\ (Received 14.10.2015. Accepted 10.02.2016)
}

SUMMARY

Portuguese wine is recognized as an important source of economic revenues for Portugal. However, revenues from this product declined in most foreign markets in the decade from 2001-2011. In this paper, we will develop an original attempt to identify the most important determinants of the value of Portuguese wine exports and the efficiency levels for each destination country. Our results revealed that the value of Portuguese wine exports has a positive relationship with the size of the government in each destination country, the rural population of the destination country, and real GDP per capita, among other variables. The efficiency of wine exports increased because of the level of inflation and Foreign Direct Investment per capita in the destination economies. We also found that the most efficient destinations are those where Portuguese is the native language, and two of the less efficient cases are Poland and the United States of America, which are cases that deserve special attention from Portuguese exporters and foreign policies.

\section{RESUMO}

O Vinho português é reconhecido como uma importante fonte de receitas económicas de base agrícola para Portugal. No entanto, as receitas deste produto diminuíram na maioria dos mercados estrangeiros na década 2001-2011. Neste artigo, iremos desenvolver uma tentativa original para identificar os determinantes mais importantes do valor das exportações de vinhos portugueses e os níveis de eficiência para cada país de destino. Os nossos resultados revelaram que o valor das exportações de vinhos portugueses tem uma relação positiva com o tamanho do setor público em cada país de destino, com a população rural do país de destino, e com o PIB real per capita, entre outras variáveis. A eficiência das exportações de vinho aumenta por causa do nível de inflação e do investimento direto estrangeiro per capita nas economias de destino. Também descobrimos que os destinos mais eficientes são aqueles onde o português é a língua nativa, e dois dos casos menos eficientes são a Polónia e os Estados Unidos da América, que são casos que merecem atenção especial por parte dos exportadores portugueses.

Key words: Portuguese exports, Stochastic Frontiers, wine exports.

Palavras-chave: exportações portuguesas, Fronteira Estocástica, exportações de vinho.

\section{INTRODUCTION}

Portuguese wine is one of the most famous Portuguese exports (Cohen, 2014; IVV, s.d.). Roman authors had already discussed its quality (IVV, 2014) centuries before David Ricardo used Portuguese wine to identify the Comparative Advantages produced by the Treaty of Methuen.

These exports include the well-known Oporto Wines (Ruby, Tawny, and White), Madeira Wines and Table Wines (Red Wines, White Wines and Green Wines are the most significant groups) (Wines of Portugal, 2014). However, this traditional Portuguese export has faced a twofold challenge over the last decade (Observatório dos Mercados Agrícolas e das Importações Agro-Alimentares, s.d.). First, purchases by the typical groups of consumers (Cardeira, 2009) in the most important destination countries are not increasing sufficiently. Second, as a consequence of the first challenge, the per capita value of wine exports in some destination country has declined over the studied period (COM, 2012). This second 1

This is an Open Access article distributed under the terms of the Creative Commons Attribution License (http://creativecommons.org/licenses/by/4.0), which permits unrestricted use, distribution, and reproduction in any medium, provided the original work is properly cited. 
challenge can be perceived as an undervaluation of this important source of Portuguese export revenues and implies that new policies designed to return these revenues to traditional levels are necessary. In this study, we intend to contribute to this debate.

The most important destination countries for Portuguese wine exports (excluding fortified wine with PDO Port and Madeira) in the studied period (from 2001 to 2011), were Angola, France, Germany, the United Kingdom, the United States of America, Switzerland, Mozambique, Canada, Brazil, Sweden, Cape Verde, Belgium, the Netherlands, Norway, Luxembourg, Spain, Poland, Macau, Guinea Bissau and Sao Tome and Principe (Figure 1).
The ratio of the value of Portuguese wine exports per population of the destination country (measured in euros, and excluding fortified wine with PDO Port and Madeira) in each destination country is the primary variable of the model considered here. The average value of this ratio in the analyzed period is the highest in the following five countries: Angola, Switzerland, Cape Verde, Luxembourg and Macau. For example, Luxembourg imports an average of approximately nine euros per capita of Portuguese wine annually, Cape Verde and Macau import approximately six euros per capita annually and Angola imports approximately two euros per capita annually (Figure 2).

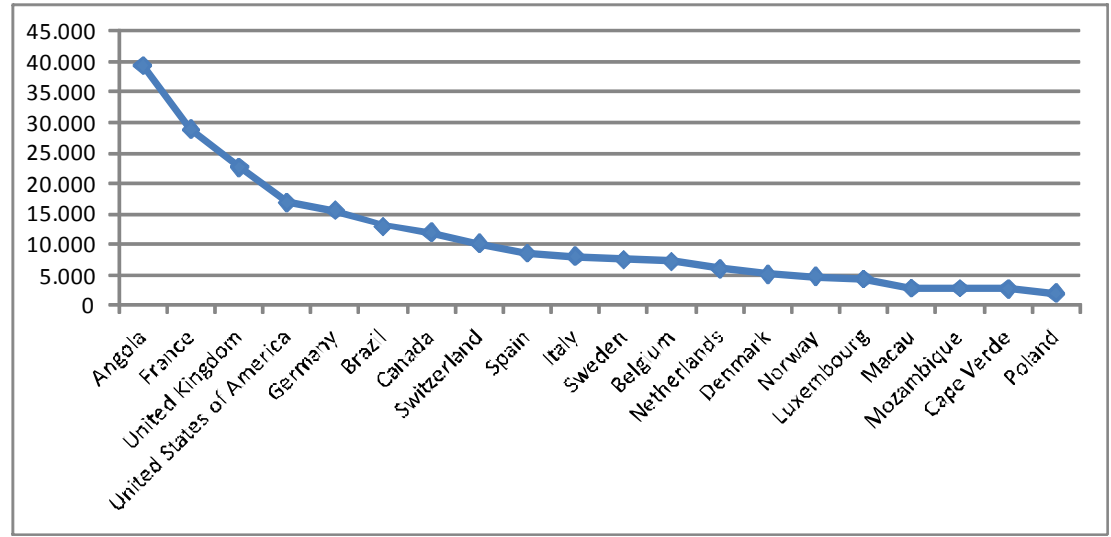

Source: Own calculus based on Instituto da Vinha e do Vinho (2012)

Figure 1. Value of Portuguese Wine exports (1000 euros) of destination country (average 2001-2011).

Valor das exportações de vinho portuguesas (1000 euros) por país de destino (média 2001-2011).

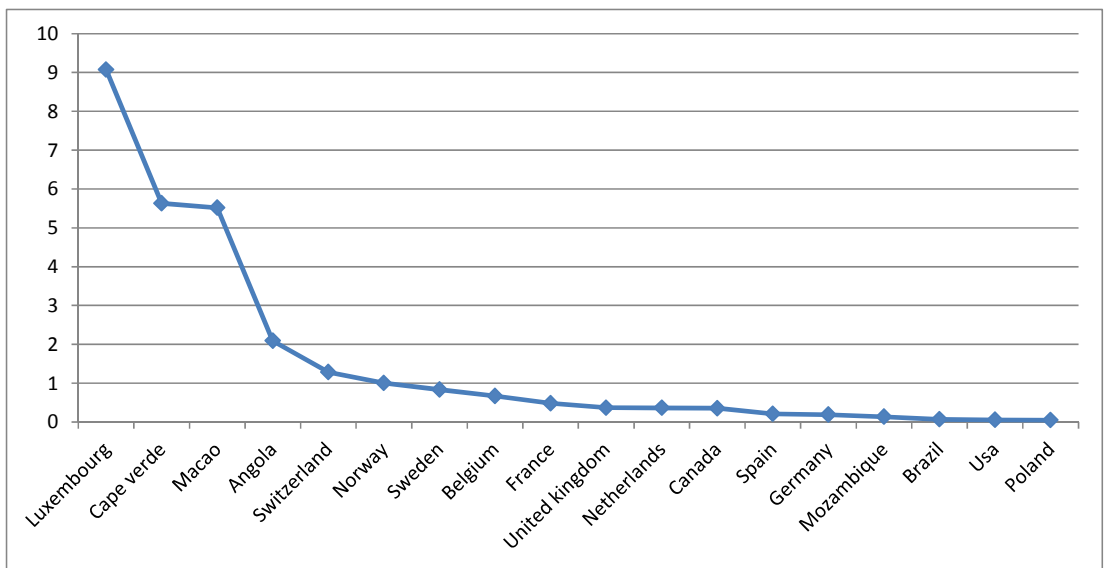

Source: Own calculus based on Instituto da Vinha e do Vinho (2012) and World Development Indicators (2012)

Figure 2. Value of Portuguese Wine exports (euros) per resident of destination country (average 2001-2011).

Valor das exportações de vinho portuguesas (euros) por residente do país de destino (média 2001-2011). 
From Figure 2, we can observe that countries such as France, Germany, the United States of America, Mozambique, Brazil and Spain exhibit relatively modest values of Portuguese wine consumption per capita, despite the strong relationships of Mozambique and Brazil with Portugal (due to a common native language and a relevant migration flow in both directions).

Other interesting observation relates to the value of Portuguese wine exports which increased over the past decade in some important cases, such as Angola, Cape Verde, Switzerland and the United Kingdom. In Angola, the value of Portuguese wine exports increased in the period from 2001 to 2011, from approximately fifty cents per capita to approximately four euros per capita. Consumption in Cape Verde increased from approximately three euros per capita in 2001 to seven euros per capita in 2011. We also observed growth in Switzerland: from approximately fifty cents per capita (in 2001) to approximately two euros per capita (in 2011). Consumption in the United Kingdom increased from thirty cents per capita in 2001 to approximately sixty cents per capita (in 2011).

The most important countries where consumption of Portuguese wine (excluding fortified wine with PDO Port and Madeira) decreased were France and Spain. The consumption trend in France declined over this period, from approximately eighty cents per capita to approximately forty cents per capita. Spain also exhibited a decrease from forty cents per capita (in 2001) to twenty cents per capita (in 2011). Consumption in the other countries remained fairly stable around their individual average values.

Therefore, this work is novel for two main reasons. First, this work analyzes a set of determinants for a specific variable: the per capita value of Portuguese wine exports in each destination country. Second, this work discusses the efficient levels of this value using a Stochastic Frontier analysis.

In the following sections, we will attempt to identify the determinants of this heterogeneity through a literature review. Then, we will test the identified determinants and the efficiency values derived from this distribution of values for Portuguese wine. This attempt is necessary for identifying the least efficient cases (with the lowest scores) that exhibit the larger potential to the growth of Portuguese wine consumption and that demand more accurate export policies toward the increase of this efficiency.

This contribution is the first to estimate Stochastic Frontiers in the literature on Portuguese wine exports and considering the outputs obtained by these econometric methods, namely those related with the Stochastic Frontier Models of efficiency.

The results show that there is many potential to improve the Portuguese wine exports, especially at the North-American and at the Polish markets. The United States of America and the Poland are two of the destinations with the greatest potential for improving the efficiency of Portuguese wine exports, namely by larger Portuguese exports but also by recurring to the exports of more expensive wines for these economies.

\section{The value of Portuguese wine in foreign markets - describing the problem and reviewing the literature}

Wine is an important economic sector in many European countries, such as France, Italy, Spain, Greece and Portugal (Viviani, 2009). Several studies have already discussed European wine exports; in this article, we also highlight the contributions of Karelakis et al. (2008), Gwynne (2006) and Fischer and Gil-Alana (2009).

Using data from Greek wine exporters, Karelakis et al. (2008) analyzed the export determinants of wine companies and found that the main factors that influenced wine exports were competitive export advantages (firm export competence, knowledge related to export channels, product adaptation, competitive price, and distributor support), environmental factors (economic hostility and price competition), and the conditions necessary for the development of an export channel (information exchange and cooperation).

In a similar manner, Gwynne (2006) studied wine exports, especially to markets that are more open because they are particularly export-oriented. This analysis highlighted the importance of the relationship between export-orientation and the concentration of exports in agro-industry products.

Using data from the period 1998-2005, Fischer and Gil-Alana (2009) analyzed the influence of the diversification of imports in a destination country as a determinant of that country's wine imports. Fischer and Gil-Alana (2009) concluded that increased import levels tend to be associated with a more diverse basket of imports.

However, in a global perspective and before going deeper for the Portuguese context, it is important to identify the main factors that the literature refer as determinants of the wine exports. When studying Trade or International Relationships, scholars not only discuss the volume of trade (imports and exports) but also the value of this trade flow. In this 
paper, we will study the value of outflows, i.e., the value of exports. Roughly speaking, we can identify the value of exports as the sum of the products of each unit of exported product by its price in the destination country.

Most papers on the determinants of the value of exports are described as "fragmented and diversified" (Sousa et al., 2008). These authors analyzed 52 papers to identify the factors determining the value of Portuguese exports. Sousa et al. (2008) divided the determinants of export value into two dimensions: internal and external. On the external dimension, Sousa et al. (2008) primarily considered the characteristics of destination countries; on the internal dimension, Sousa et al. (2008) focused on the characteristics of domestic firms.

Baldauf et al. (2000) identified empirical studies on exports and attempted to group the most statistically significant variables used in these studies. Therefore, Baldauf et al. (2000) also identified two groups of explanatory variables: those related to environmental characteristics (related to socio-cultural and political variables affecting importer-exporters), firm characteristics (related to demographic and management dimensions) and business strategies (related to variables regarding the differentiation of products and their prices). These variables were used to explain export performance, namely, export effectiveness, export intensity and the volume of export sales.

Using econometric techniques and OECD data for 17 countries over a period from 2001-2007, Seo et al. (2012) studied the relevance of three factors on exports: the real exchange rate, the technological variables and the institutional environment. Seo et al. (2012) found positive effects for the technological variables (research and development intensity and fixed capital formation) and the institutional environment (human capital investment, free trade environment and English as a native language). Therefore, Jongwanich (2010), Agosin et al. (2012) and Seo et al. (2012) analyzed other determinants, such as the influence of exchange rates, world demand, the level of foreign direct investment in the destination country and the destination country's level of production.

Dean et al. (2000) examined other variables, with a particular focus on trade costs. They specifically considered high transportation costs, the lack of a skilled and flexible labor force, exchange rate management, and the high costs of overseas travel, interest rates and inflation. This study concluded that these variables had a statistically significant effect on export performance.
Balabanis and Katsikea (2003) analyzed the relationship between entrepreneurship and export performance, measured as high export values. They identified specific organizational and environment factors to be determinants of export values. These authors concluded that export firms that increased revenues in dynamic markets performed better in export markets.

In a similar manner, Sousa et al. (2008) tested groups of variables to determine an efficient export strategy. In addition to combining four main strategies (product strategy, price strategy, promotion strategy, and distribution strategy), they also highlight the importance of considering the characteristics of consumers in a given market, namely, the levels of market research and market expansion, the consumers' ages and education levels, and the legal and political institutions affecting these consumers. Sousa et al. (2008) concluded that these characteristics must be understood to reach efficient export levels.

Using a similar approach, Brodrechtova (2008) found that the following factors produce the most successful export marketing strategies: well-defined company goals, use of the most efficient type of production and strength of a firm's export motivation. Another factor is a high-quality resource-based perspective focused on optimizing the level of foreign direct investment, financial resources and knowledge of foreign markets. Finally, the author also identified an understanding of local institutions (recognizing the political, economic and security characteristics). Brodrechtova (2008) concluded that physical and relational resources and the domestic institutions in the destination economy were the most important factors for generating a high export level, which is often correlated with high-quality foreign direct investment.

$\mathrm{Lu}$ et al. (2012) investigated the role of other institutional dimensions, namely, the role of the public sector and public agents, which are able to influence competitive intensity. Competitive intensity is found to be a crucial determinant of firm performance in foreign markets. Lu et al. (2012) concluded that the characteristics of foreign markets are often outside the control of the export companies, but these characteristics are significant determinants of the export values.

In summary, export values are affected by three general factors:

- Consumption habits (related to specific groups of importers), following Baldauf et al. 
(2000), Barros and Santos (2007), and Seo et al. (2012);

- Internal lobbies (related to the dimension of the public sector and the susceptibility of the government to pressure from specific groups), in line with Lu et al. (2012) and Trade environment (Seo et al., 2012);

- Income factors (related to the ability of an importing country to acquire a reasonably diversified basket of goods valued at market prices, including tariffs and non tariffs barriers), following Balabanis and Katsikea (2003), and the inflation rate and other costs associated with the trade (Dean et al., 2000);

The specific case of Portuguese wine exports exhibits some particularities. Cabral (2004) studied the position of Portuguese exports in the international market and found that Portugal experienced a significant decline in market share in the original 15 European Union member states in the period from 1997-2005.

Cabral and Esteves (2006) also investigated changes in the market share of Portuguese exports using a sample of eight countries and twelve products, which represented over $70 \%$ of Portuguese manufacturing exports in the period from 1999-2005, while accounting for the composition of the products exported and geographic effects. They concluded that Portugal lost market share in this period, primarily because of the product composition of Portuguese exports. Geographic proximity exerted a positive effect on the market share of Portuguese exports.

Barros and Santos (2007) investigated the efficiency of cooperatives and private companies in the Portuguese wine sector using DEA (data envelopment analysis) to evaluate organizational competitiveness in the period from 1996-2000. The authors found that the cooperatives were more efficient than private enterprises, leading to more significant effects on wine demand in rural areas compared to urban areas.

Regarding these issues, Maietta and Sena (2010) found that wine production and exports are influenced by interest groups, namely, financial and political groups, which generate specific pressures than can have positive effects on wine production and trade efficiency.

Therefore, considering the European and the Portuguese experiences as wine exporters, we can highlight some additional determinants:

- The mean export prices (Baldauf et al., 2000; Karelakis et al., 2008; and Sousa et al., 2008);
- The Exchange rates (Dean et al., 2000; Jongwanich, 2010; Agosin et al., 2012; and Seo et al., 2012);

- the Portuguese wine market shares in the specific country's market (Cabral, 2004; Cabral and Esteves, 2006);

- The inflation rate and other costs associated with the wine trade (Dean et al., 2000);

- A secure environment in the destination economy (following Edwards and Alves, 2006, and Maietta and Sena, 2010);

- $\quad$ The direction (pro-imports or pro-exports) of the globalization processes in the destination countries, as discussed by Gwynne (2006);

- The overall attractiveness of the destination economy, alternatively measured by the level of foreign direct investment (Brodrechtova, 2008).

However, this work intends to go further than conventional analyses of the determinants of the value of Portuguese wine exports. We will analyze the efficiency of the value of exports in each of the destination countries for Portuguese wine. Therefore, we will identify the markets that, given their national characteristics, optimize the traded value of Portuguese wine and the markets that, conversely, exhibit the greatest potential to increase the value of this important Portuguese product. We are going to recur to a proper method to discuss the efficiency levels of achieving socio-economic objectives - the estimation of Stochastic Frontiers and to the respective analyses. The next section describes our empirical procedures.

\section{MATERIAL AND METHODS}

\section{Models and estimation method}

In order to simultaneously evaluate the determinants of Portuguese wine exports and their efficiency scores, we are going to use an econometric method that has been found proper to simultaneously achieve these two goals - the Stochastic Frontier Model (Battese and Coelli, 1988; Cullinane and Song, 2006).

We will estimate a Stochastic Frontier Model for the values of Portuguese wine exports in destination countries, considering the most important factors identified by the literature. In our second step, we will analyze a range of social and economic factors that may explain the diversity of efficiency scores obtained for the different destination countries. Finally, this estimation attributes an "efficiency" score to each observation (Destination country/year). 
In this first step, we assume that Portuguese wine exporters attempt to optimize the allocation of Portuguese wine to each i destination country using N inputs. We employ panel data (i countries/ $t$ years). Thus, following Battese and Coelli (1988), a Stochastic Frontier Model for the per capita value of Portuguese wine exports in each destination country can be written as

$$
\text { Wine }_{i t}=f\left(x_{i t} ; \beta\right) \exp \left\{v_{i t}\right\} T E_{i t}
$$

We assume that Wine $_{i t}$ is a scalar of the output of the process that we intend to investigate - the per capita value of Portuguese wine exports for each destination country $i, \mathrm{i}=1, \ldots, \mathrm{I}$ in year $t . x_{i t}$ is the vector of $\mathrm{N}$ determinants of per capita value of Portuguese wine exports for each destination country observed in year $t$. $\mathrm{f}($.) is the frontier of the per capita value of Portuguese wine exports for each destination country, and $\beta$ is the vector of parameters to be estimated. The Stochastic Frontier consists of two dimensions: a common component, $f($.), affecting all destination countries and each destination-country-specific random component, $\exp \{v i t\}$. The technical efficiency of each destination country $\mathrm{i}$ is given by $\mathrm{TE}_{\mathrm{it}}$. By rearranging equation (1), we obtain

$$
T E_{i t}=\frac{\text { Wine }_{i t}}{f\left(x_{i t} ; \beta\right) \exp \left\{v_{i t}\right\}}
$$

Following equation (2), our efficiency index measures the ratio of the observed per capita value of Portuguese wine exports received by the $i$-th destination country to the maximum feasible amount.

According to Cullinane and Song (2006), we assume that $f($.) takes the usual log- Cobb-Douglas form. Although the limitations of this form, there are various strong justifications for its use (Cullinane and Song, 2006): the form does not demand particular assumptions on the empirical estimation, the estimated coefficients for the inputs can be interpreted as mean elasticities, and the policy implications can be more directly discussed from the estimation. The model in (1) can then be written as

$$
\ln \text { Wine }_{i t}=\beta_{0}+\sum_{n} \beta_{n} \ln x_{n i t}+v_{i t}-u_{i t} \text { (Eq. 3) }
$$

We maintain the notation employed in equations 1 and 2 and the identification of each of the abovementioned elements. However, note that vit (the idiosyncratic error term) is distributed independent of $u_{i t}$, and

$v_{i t} \sim N\left(0, \sigma_{v}^{2}\right)$.
Additionally, we assume that $u_{i t}$ is the nonnegative inefficiency term for the $i$-th destination country, and

$u_{i t} \sim N\left(m_{i t}, \sigma_{u}^{2}\right)$

According to the previous equation (equation 3), per capita value of Portuguese wine exports expected for a given destination country $i$ in a given year $t$ depends on a constant $\left(\beta_{0}\right)$, the set of $\mathrm{N}$ determinants, the inefficiency measure $u_{i t}$, and a set of random variables $\left(\mathrm{v}_{\mathrm{it}}\right)$ following the typical assumption of normally distributed error terms $\left[i i d \sim N\left(0, \sigma_{v}^{2}\right)\right]$.

We also assume that $u_{i t}$ depends on a set of nonnegative $^{1}$ variables. As established in the literature, these variables are assumed to be independently distributed as truncations at zero of the $N\left(m_{i t}, \sigma_{u}^{2}\right)$ distribution. The mean of this distribution is a function of vector $z$ of the variables influencing the efficiency of the destination countries in generating high per capita values of Portuguese wine exports.

$m_{i t}=\delta * z_{i t}+\varepsilon_{i t}$

where $\delta$ is a vector of parameters to be estimated, and $\varepsilon_{i t}$ is estimated under the iid assumptions.

Following Battese and Corra (1977), equations 3 and 4 constitute a two-equation system.

A simultaneous maximum likelihood estimation of this system is expressed in terms of the variance parameters

$\sigma^{2}=\sigma_{v}^{2}+\sigma_{u}^{2}$ and

$\gamma=\frac{\sigma_{u}^{2}}{\sigma_{u}^{2}+\sigma_{v}^{2}}$ to provide asymptotically efficient estimates. A test of the significance of the parameter $\gamma$ is therefore a test of the significance of the specification of the system (Battese and Corra, $1977)^{2}$

An alternative estimation method would be the Method of Moments, which was suggested by Olson et al. (1980) and Coelli (1995). Following Behr and Tente (2008), the Method of Moments is especially indicated for a small number of observations (less

\footnotetext{
${ }^{1}$ See Battese and Corra (1977) or Battese and Coelli (1995).

${ }^{2}$ As Battese and Corra (1977) states, the system composed by equations 3 and 4 is estimated by maximum likelihood. Alternative methods (like panel data estimations using fixed-effects) provided converging results to these (available under request). However, fixed-effects estimations are more exposed to heteroskedasticity problems, as Battese and Corra (1977) recognizes.
} 
than 25); for a larger number of observations, Behr and Tente (2008) prefer Maximum Likelihood estimations. In spite of this serious limitation of the Method of Moments, we also estimated our equations considering this Method, with close results. Full details are available under request.

\section{Data}

In this section, we test equation (3), which addresses the efficiency of the allocation of Portuguese wine in each destination country during the period from 20012011. We consider the following independent variables $\left(\mathrm{x}_{\mathrm{it}}\right)$ suggested by the literature:

- Rural Population, as a percentage of total population;

- $\quad$ Age Dependency Ratio;

- $\quad$ Government size (measured by the ratio of Public Expenditures to GDP);

- Value of Imports;

- $\quad$ And Real GDP per capita.

As we noted above, these variables reflect the three main factors identified in the literature as relevant for wine imports: "consumption habits related to some population groups", "internal lobbies," and "income factors".

In discussing "consumption habits", we follow Baldauf et al. (2000) and Seo et al. (2012) and use the percentage of the rural population in the total population and the age dependency ratio as explanatory variables. In fact, the consumer behavior of the market segments, found through geographic or social criteria (among others) are different as found recently, for example, Grosso et al. (2014) or Trotta et al. (2015). We expect that a larger rural population in a destination country leads to greater demand for wine, a traditional product more commonly consumed by rural people (Baldauf et al., 2000). Obviously, we do not ignore that different wines are consumed by different people in a country - urban people tend to consume different drinks products than rural people or aged people opt for other wines than younger consumers. The same differentiation applies to the large set of Portuguese wines. However, following Baldauf et al. (2000) and Seo et al. (2012), countries with larger rural populations tend to consume more wine than countries with smaller rural populations. A greater age dependency ratio tends to reduce demand from this group of elder consumers for health and income reasons; it also tends to reduce demand from the youngest groups because of legal restrictions.

To analyze "internal lobbies," we use the "size of the public sector," measured by the share of public expenditures in real GDP. As Lu et al. (2012) argue, the size of the public sector is a reasonable 'proxy' for the existence of internal lobbying groups, and a more pronounced presence of certain lobbies tends to be associated with more pressure for certain imports, namely, from investors from the importer country seeking to invest in the exporter country. In fact, Kollmeyer (2015) found statistical significant relationships among the public sector expenditure and the imports behavior.

Finally, as destination countries are also typically affected by common income factors (Balabanis and Katsikea, 2003), we also consider "the value of imports" and "real per capita GDP" as explanatory variables. According to Balabanis and Katsikea (2003), there is a positive correlation between high average national income and total imports in destination countries. As we were concerned by the potential for endogeneity between these two variables, we performed endogeneity tests and obtained values allowing us to reject the hypothesis of endogeneity between real per capita GDP and imports for the sample of countries importing Portuguese wine (full results available upon request).

A recent set of studies has discussed how the direction of the openness in an economy influences the composition of imports. For instance, countries emphasizing exports also tend to substitute some of their imports for their own production. This leads to less efficient allocations of the substituted imports (Agosin et al., 2012). Conversely, and as Jongwanich (2010) argues, attractive economies receive greater Foreign Direct Investment. This attractiveness is also accompanied by greater imports, especially in quality goods coming from the investor countries (Jongwanich, 2010). Increasing levels of domestic inflation tend to be associated with an increase in the value of imports, which are perceived as good 'reserves of value' (Dean et al., 2000). This tends to increase the efficiency of these imports from the perspective of the countries that export them. Finally, high levels of military expenditures indicate that a given economy faces serious national security problems but also comprises a certain composition of the import basket, which contains fewer luxury goods. Therefore, we expect that higher values of military expenditures in the destination countries reduce the efficiency of Portuguese wine exports to those countries.

- We assume that the vector $z$ of variables influencing the efficiency of Portuguese wine exports in each destination country is composed of the four dimensions of these destination countries suggested by the literature: direction of openness 
in the economy; attractiveness of the economy as assessed by international investors; price stability in the economy; and national security (Dean et al., 2000; Edwards and Alves, 2006; Jongwanich, 2010; Agosin et al., 2012). Therefore, in following with the identified authors, we will proxy for these dimensions using the following variables:

- The value of national exports (as a \% of each destination country's GNP), following Agosin et al. (2012);

- The value of Foreign Direct Investment (as a $\%$ of each destination country's GNP), following Jongwanich (2010);

- The level of inflation, following Dean et al. (2000);

- $\quad$ And the value of military expenditures (as a $\%$ of each destination country's GNP), following Edwards and Alves (2006) ${ }^{3}$.

The data sources for our variables are shown in Table I.

The two main data sources are the Portuguese Institute for Wine and Vineyards (IVV, Instituto do Vinho e da Vinha) ${ }^{4}$ and the World Development Indicators $(2012)^{5}$. The IVV (2012) provided us with the values of Portuguese wine exports to countries from around the world, namely, in the twenty main Destination countries analyzed here. Then, using the population values provided by the World Development Indicators (2012), we constructed our dependent variable: the per capita value of Portuguese wine exports in each destination country. The World Development Indicators (2012) provided values for the remaining variables.

We studied the twenty principal importers of Portuguese wine over the last decade (2001-2011). The databases available from previous years do not contain precise values. The first reason for this imprecision is due to the heterogeneity of the data sources. As previously noted (see Table I), we refer to two data sources simultaneously. We must therefore devote special attention to constructing a balanced database. The second reason is due to the availability

\footnotetext{
${ }^{3}$ We also were concerned by the potential endogeneity between "exchange rates" and "inflation rate" and among "real per capita GDP", "Portuguese Export Market shares in each specific country's market", and "mean export prices". We run tests on the endogeneity of these variables and we obtained values not allowing us to reject the null hypotheses. Full details are available under request. Therefore, the variables "exchange rates", "Portuguese Export Market shares in each specific country's market", and "mean export prices" were not included in our final model.

${ }^{4}$ See http://www.ivv.min-agricultura.pt/np4/37

${ }^{5}$ See http://data.worldbank.org/country/
}

of data from destination countries. Because some destination countries' data suffer from a serious availability problem, economic studies on these destination countries (especially African countries) are concentrated on recent years, for which more data are available.

\section{Table I}

Data and Sources

Dados e fontes

\begin{tabular}{|c|c|}
\hline Variable & Source \\
\hline $\begin{array}{l}\text { Value of Exports of Portuguese } \\
\text { Wine per resident of destination } \\
\text { country }(\log )\end{array}$ & $\begin{array}{l}\text { IVV }(2012) / \quad \text { World } \\
\text { Development } \quad \text { Indicators } \\
(2012) / \text { Own calculus }\end{array}$ \\
\hline Mean export prices & $\begin{array}{lr}\text { IVV } \quad(2012) / & \text { World } \\
\text { Development } & \text { Indicators } \\
(2012) / \text { Own calculus }\end{array}$ \\
\hline Exchange rates & $\begin{array}{l}\text { European Central Bank / } \\
\text { Eurosystem (2013) }\end{array}$ \\
\hline $\begin{array}{l}\text { Portuguese Export Market shares } \\
\text { in the specific country's market }\end{array}$ & $\begin{array}{l}\text { International Organization of } \\
\text { Vine and Wine (2013) }\end{array}$ \\
\hline $\begin{array}{l}\text { Rural Population (log of } \\
\text { \%population) }\end{array}$ & $\begin{array}{l}\text { World Development Indicators } \\
\text { (2012) }\end{array}$ \\
\hline $\begin{array}{l}\text { Destination country's Imports } \\
\text { (log of } \% \text { GDP })\end{array}$ & $\begin{array}{l}\text { World Development Indicators } \\
\text { (2012) }\end{array}$ \\
\hline Government size $(\log )$ & $\begin{array}{l}\text { World Development Indicators } \\
\text { (2012) }\end{array}$ \\
\hline Age Dependency Ratio (log) & $\begin{array}{l}\text { World Development Indicators } \\
\text { (2012) }\end{array}$ \\
\hline Real GDP per capita (log) & $\begin{array}{l}\text { World Development Indicators } \\
\text { (2012) }\end{array}$ \\
\hline $\begin{array}{l}\text { Military expenditures (log of } \\
\% \text { GDP) }\end{array}$ & $\begin{array}{l}\text { World Development Indicators } \\
\text { (2012) }\end{array}$ \\
\hline Inflation rate $(\log )$ & $\begin{array}{l}\text { World Development Indicators } \\
\text { (2012) }\end{array}$ \\
\hline FDI per capita (log of $\%$ GDP) & $\begin{array}{l}\text { World Development Indicators } \\
\text { (2012) }\end{array}$ \\
\hline $\begin{array}{l}\text { Value of destination country's } \\
\text { exports }(\log )\end{array}$ & $\begin{array}{l}\text { World Development Indicators } \\
\text { (2012) }\end{array}$ \\
\hline
\end{tabular}

The empirical analysis was performed using panel data. Table II reports descriptive statistics for the variables used to estimate our system of equations.

\section{RESULTS AND DISCUSSION}

Table III presents the Maximum-Likelihood estimates of the parameters of the Stochastic Frontier for the per capita value of Portuguese wine exports in each of the twenty most significant destination countries (2001-2011). We have also computed additional specifications of this Stochastic Frontier (with other control variables) and obtained similar results (available upon request). In order to discuss the exogeneity at our two-equations model, we followed Antonakis et al. (2010) and their 10 empirical rules 
and respective tests. In order to keep space, the details concerning this discussion will be provided if requested. As a summary, we can state that the related tests did not reveal significant endogeneity threats at the final specification of our model, exhibited at Table III.

Table II

Descriptive statistics

Estatísticas descritivas

\begin{tabular}{|c|c|c|c|c|c|}
\hline Variable & Observations & Mean & Standard Deviation & Minimum & Maximum \\
\hline $\begin{array}{l}\text { Value of Exports of Portuguese Wine per } \\
\text { resident of destination country }(\log )\end{array}$ & 216 & -7.646 & 1.674 & -13.148 & -4.353 \\
\hline Mean export prices & 240 & 1.688 & 0.922 & 0.011 & 3.396 \\
\hline Exchange rates (/1 euro) & 155 & 1159.1 & 4351.9 & 0.609 & 25931.3 \\
\hline $\begin{array}{l}\text { Portuguese wine market shares in the } \\
\text { specific country's market }\end{array}$ & 188 & 33.455 & 74.981 & 0.037 & 67.234 \\
\hline Rural Population (log of \%population) & 228 & 3.172 & 0.683 & 0.922 & 4.261 \\
\hline $\begin{array}{l}\text { Destination country's Imports (log of } \\
\% \text { GDP) }\end{array}$ & 231 & 25.013 & 2.910 & 17.552 & 28.797 \\
\hline Government size $(\log )$ & 170 & 2.909 & 0.363 & 2.148 & 3.634 \\
\hline Age Dependency Ratio $(\log )$ & 240 & 4.010 & 0.288 & 3.227 & 4.612 \\
\hline Real GDP per capita (log) & 192 & 10.303 & 0.973 & 7.211 & 11.130 \\
\hline Military expenditures (log of \%GDP) & 203 & 0.445 & 0.534 & -0.694 & 2.000 \\
\hline Inflation rate $(\log )$ & 227 & 1.126 & 1.101 & -2.429 & 6.001 \\
\hline FDI per capita (log of $\%$ GDP) & 221 & 1.374 & 1.158 & -2.292 & 5.151 \\
\hline Value of destination country's exports $(\log )$ & 233 & 24.235 & 3.371 & 14.805 & 28.067 \\
\hline
\end{tabular}

Table III

Maximum-likelihood estimates of parameters of the Stochastic Frontier for Portuguese exports of wine on 20 destination countries (2001-2011)

Estimativas de probabilidade máxima dos parâmetros de Fronteira Estocástica para as exportações portuguesas de vinho nos 20 Países de Destino (2001-2011)

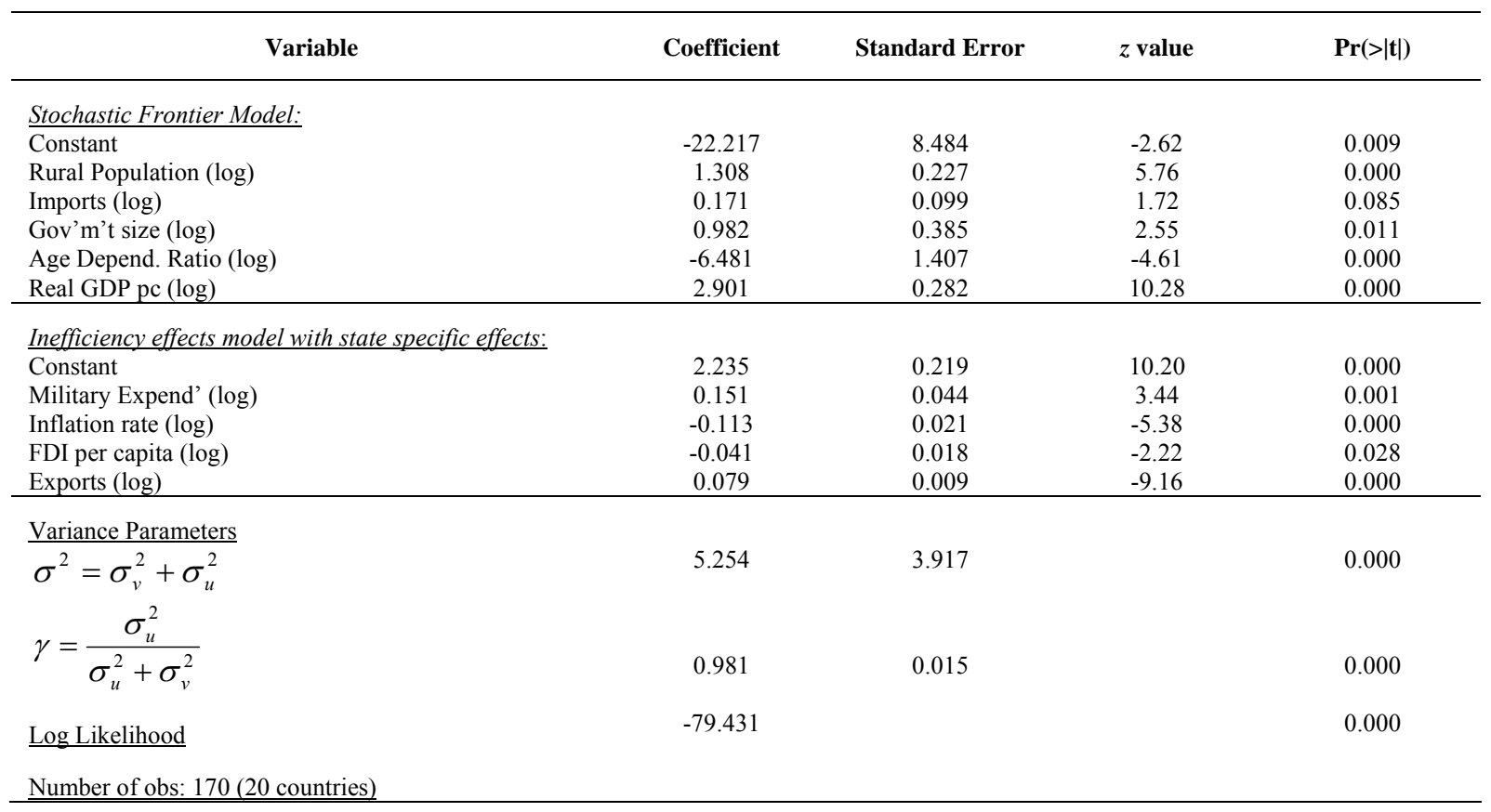


Table III illustrates that a higher value for the Rural Population in a destination country is correlated with a higher expected value of Portuguese wine exports in that country. This evidence follows Barros and Santos (2007), who claimed that wine imports are positively influenced by rural consumers. A larger population living in rural areas increases demand for wine, leading to additional pressures on wine imports.

We also found that a higher total import value in a given destination country leads to a higher value of Portuguese wine exports for that destination country. Our results confirm the findings of Fischer and GilAlana (2009), who claimed that higher imports tend to be associated with a more diverse import basket. Therefore, the value of wine imports is more likely higher in a country with a more imports than in a country with fewer imports.

We also found a significant and positive coefficient for the variable related to government size. A larger share of public expenditures in the gross national product is a widely employed proxy for the presence of interest groups in the public sector ( $\mathrm{Lu}$ et al., 2012). Other studies (Maietta and Sena, 2010) show that a higher number of interest groups in the public sector diversifies the imports of the country and can lead to more open economies. As a result, we also find that Portuguese wine exports tend to be more efficiently allocated in destination countries with enlarged public sectors.

Interestingly, when the Age Dependency Ratio (elderly persons per worker) for a destination country increases, our results suggest an expected reduction in the per capita value of Portuguese wine exports for that destination country. As in Sousa et al. (2008), we can argue that this evidence indicates that Portuguese wine is consumed by workers to a greater extent than by retired or elderly people in destination countries.

As a final observation on the determinants of the Stochastic Frontier for the per capita value of Portuguese wine exports in each destination country, we note that the coefficient for the relevance of real GDP per capita in the destination countries is statistically significant (at a significance level lower than $1 \%$ ). This evidence leads us to conclude that a higher average income in a Destination country can be identified as a determinant for the per capita value of Portuguese wine exports in each destination country in our sample.

We will now discuss the variables affecting the inefficiency levels of the value of Portuguese wine exports. Recall that an "efficient case" in our study does not simply mean a case (a destination country) that attracts a higher value of Portuguese wine exports in absolute terms. Instead, an "efficient case" implies that a country generates a high level of per capita value of Portuguese wine exports in a given destination country given that country's characteristics. For example, suppose that the rural population in a destination country is a significant factor affecting Portuguese wine exports. Country A is therefore more efficient than country B in trading Portuguese wine if one hundred monetary units of Portuguese wine exports per resident of $\mathrm{A}$ are allocated in A (where sixty rural people live), and two hundred monetary units of Portuguese wine exports per resident of $\mathrm{B}$ are allocated in $\mathrm{B}$ (where two hundred rural people live).

We found that higher Foreign Direct Investment and higher inflation rates promote more efficient values for Portuguese wine exports in destination countries (Brodrechtova, 2008). These variables exhibit negative estimated coefficients, implying that higher values of these variables are correlated with smaller values of the inefficiency parameter. This result suggests that an attractive destination country for foreign investment can receive more Portuguese wine exports, even if some of the direct determinants (i.e., the rural population living in that country or the national average income) do not have the most significant values. The explanation for the direction found for the inflation rate is standard: countries having high inflation rates tend to value imports, increasing the value of imports, which are viewed as reserves of value (Dean et al., 2000).

We follow Edwards and Alves (2006) in concluding that efficient destinations exhibit lower levels of military expenditures because these expenditures generally fail to attract investors. This explains why we found a positive coefficient for "military expenditures" (correlated with increases in the inefficiency parameter in our model). We also found a positive coefficient for the "value of exports" in destination countries. This evidence is in line with Gwynne (2006), who argued that it is more difficult to efficiently allocate exports in countries that are also strongly motivated to export their own products.

The variance parameters exhibit estimated coefficients that are statistically significant. Following Battese and Coelli (1988), this favors the overall statistical significance of the model and the selected specification (identified by statistically significant values for $\sigma$ and $\gamma$ ).

The estimates presented in Table III allowed us to construct an observed efficiency score for each of the 20 destination countries between 2001 and 2011. For greater readability, we only present the Average 
Efficiency Score for each country in Table IV (full results are available upon request).

\section{Table IV}

Average score for the efficiency level (2001-2011) of the value of Portuguese wine exports

Pontuação média para o nível de eficiência (2001-2011) do valor das exportações portuguesas de vinho

\begin{tabular}{lc}
\hline \multicolumn{1}{c}{ Country } & Average Score (2001-2011) \\
\hline Angola & $\mathbf{0 . 9 2 9 9}$ \\
Belgium & 0.8637 \\
Brazil & 0.8465 \\
Canada & 0.0385 \\
Cape Verde & $\mathbf{0 . 9 2 9 9}$ \\
France & 0.0891 \\
Germany & 0.0447 \\
Guinea Bissau & $\mathbf{0 . 9 2 9 9}$ \\
Luxembourg & 0.8515 \\
Macau & $\mathbf{0 . 9 2 9 9}$ \\
Mozambique & $\mathbf{0 . 9 2 9 9}$ \\
Netherlands & 0.0472 \\
Norway & 0.1106 \\
Poland & $\mathbf{0 . 0 1 0 4}$ \\
S.Tome and Principe & $\mathbf{0 . 9 2 9 9}$ \\
Spain & 0.0467 \\
Sweden & 0.2756 \\
Switzerland & 0.3476 \\
UK & 0.0477 \\
USA & 0.0069 \\
\hline & \\
\hline Mean & 0.4603 \\
Standard Deviation & 0.4209 \\
Maximum & 0.93 \\
Minimum & 0.01 \\
\hline
\end{tabular}

Table IV demonstrates that the Average Efficiency Scores exhibit a low mean $(0.460)$. This value can be interpreted as further evidence that the value of Portuguese wine exports has growth potential in our sample of the most important foreign markets. In other words, one can argue that, given these values, and as our sample contains the most significant wine markets for Portugal, there is still substantial potential to improve the value of Portuguese wine exports in the destination economies.

However, some exceptional cases in Table IV are worth discussing. For example, the minimum mean values are those of the USA (0.007) and Poland (0.010). These countries serve as clear examples validating the inefficiency estimates. In the first years of the observed period (2001-2011), these countries were found (Cabral and Esteves, 2006) to exhibit significant potential as markets for Portuguese wine; during this period there was an increase in the value of exports of Portuguese wine for these destinations, despite the substantial potential for improving the value of Portuguese wine exports to these two particular markets.

At the other extreme, countries where Portuguese is the native language exhibit the maximum mean value (0.93). Recall that this efficiency score implies that, given the national conditions in these countries (Angola, Cape Verde, Guinea-Bissau, Macau, Mozambique, and San Tome and Principe), the per capita value of Portuguese wine exports allocated is high. The historical connections with the citizens of these countries and the significant flow of Portuguese emigration to these regions have contributed to this achievement, as suggested by the analysis of Cabral and Esteves (2006).

\section{CONCLUSIONS}

This study is a novel attempt to answer two research questions. First, we wished to identify the determinants that are able to influence the value of Portuguese wine exports per resident in each of the 20 most important destination countries. Second, we sought to obtain the efficiency levels of these values using Stochastic Frontier analysis.

The literature review indicated that international trade, namely, exports, is affected by several factors, some concerning the origin countries and others concerning the destination countries. Numerous authors have identified various determinants of exports, namely, those related to the destination countries. The foreign-market factors that can affect exports are grouped into political, legal, economic, geographic, cultural and social dimensions.

Wine is an important product for the Portuguese economy, particularly for all of the elements of the Portuguese economy for which wine exports and the related revenues are significant, but it is a vital product for the Portuguese agricultural sector and in rural areas of the country where the Portuguese wine sector generates reasonable incomes and creates jobs.

We observed that the most significant values for Portuguese wine exports, while controlling for the foreign country's population, concern the following countries: Angola, Switzerland, Cape Verde, Luxembourg and Macau. France, Germany, the United States of America, Mozambique, Brazil and Spain exhibit the worst values for this variable.

Following the literature we reviewed, there are three main factors identified as relevant for wine imports: "consumption habits related to some population groups", "internal lobbies," and "income factors". 
Moreover, our literature review identified that the group of variables that can influence the efficiency of Portuguese wine exports in each market is composed of four dimensions of these countries' characteristics: the direction of the openness of the economy, the attractiveness of the economy as assessed by international investors, price stability in the economy, and national security.

The results from the estimations of the Stochastic Frontier Model demonstrate that the per capita value of Portuguese wine exports in a foreign destination market is positively influenced by: Rural Population, Government size, the Value of Imports, and Real GDP per capita. However, this value is negatively influenced by the Age Dependency Ratio. The value of Foreign Direct Investment and the level of inflation in each destination country increase the efficiency of Portuguese wine exports. Conversely, higher values of military expenditures and of national exports in each destination country reduce the efficiency of Portuguese wine exports to that destination country.

Regarding the average efficiency scores, the results reveal that there is substantial potential to increase Portuguese wine exports. The United States and the Poland are two of the countries with the greatest potential for increasing the efficiency of Portuguese wine exports.

Regarding policy implications, we highlight two main lines. A first line is based on the policy implications related to the determinants of the Portuguese wine exports. As we identified the size of rural population and the real GDP per capita as positive determinants, we suggest a special attention of the Portuguese wine sector (public institutes and private agents of the sector) to the demographic and economic evolution of the trader countries in order to anticipate changes in

\section{REFERENCES}

Agosin M.R., Alvarez R., Bravo-Ortega C., 2012. Determinants of export diversification around the world: 1962-2000. The World Economy, 35(3), 295-315.

Antonakis J., Bendahan S., Jacquart P., Lalive R., 2010. On making causal claims: A review and recommendations. Leadership Quarterly, 21(6), 1086-1120.

Balabanis G.I., Katsikea E.S., 2003. Being an entrepreneurial exporter: does it pay? International Business Review, 12, 233-252.

Baldauf A., Cravens D.W., Wagner U., 2000. Examining determinants of export performance in small open economies. Journal of World Business, 35 (1), 61-79.

Barros C.P., Santos J.C.G., 2007. Comparing the productive efficiency of cooperatives and private enterprises: the Portuguese wine industry as a case study. Journal of Rural Cooperation, 35(2), 109-122. the generations' preferences. The second line puts a particular emphasis on the factors influencing the efficiency of the Portuguese sector. We observed that more opened markets and more dynamic markets are associated to higher efficiency scores; therefore, these results show that countries with lower values of trade openness and with lower inflation rates deserve a special attention by Portuguese agents given the potentiality of improving the low efficient scores got for these Portuguese wine importer countries.

Following this novel contribution, we intend to develop this area of study along four lines. First, we wish to enlarge our sample of countries and observe whether the conclusions reported here hold for a larger sample. Second, we intend to compare the efficiency levels of Portuguese wine exports in each destination country to the efficiency levels of the sum of all Portuguese exports in each destination country. Third, we wish to detail our results for the different types of Portuguese wines (i.e., Oporto wines, Madeira wines, Red Wines, or White wines). Finally, we want to explore the efficiency analysis here developed, also discussing how Portuguese wine export companies are meeting both technical and allocative efficiency criteria.

\section{ACKNOWLEDGMENTS}

The authors acknowledge the suggestions provided by two anonymous reviews of Ciência e Técnica Vitivinícola on a previous version of this paper. They also thank the suggestions provided by the participants of the Conference "Food in the Bio-based Economy; Sustainable Provision and Access" (Wageningen, 27-28 May 2015) in which a previous version of this research has been discussed. Remaining errors are authors' exclusive ones.

Battese G., Corra G., 1977. Estimation of a Production Frontie Model: with application to the pastoral zone of eastern Australia. Australian Journal of Agricultural Economics, 21, 169-179.

Battese G., Coelli T., 1995. A model for technical inefficiency effects in a stochastic frontier production function for panel data. Empirical Economics, 20, 325-332.

Battese G., Coelli T., 1988. Prediction of firm-level technical efficiencies with a generalized frontier production function and panel data. Journal of Econometrics, 38(3), 387-399.

Behr, A., Tente, S., 2008. Stochastic frontier analysis by means of maximum likelihood and the method of moments. Discussion Paper Series 2: Banking and Financial Studies No 19/2008. Deutsche Bundesbank.

Brodrechtova Y., 2008. Determinants of export marketing strategies of forest products companies in the context of transition The case of Slovakia. Forest Policy and Economics, 10, 450-459. 
Cabral S., 2004. Recent evolution of Portuguese export market shares in the European Union. Economic bulletin, pp. 79-91

Cabral S., Esteves P.S., 2006. Portuguese export market shares: an analysis by selected geographical and product markets. Economic Bulletin, pp. 57-74.

Cardeira R.F.F., 2009. Factores Críticos de Sucesso no Mercado do Vinho em Portugal e a Sustentabilidade do Sector Vitivinícola. Dissertação para obtenção do Grau de Mestre em Engenharia e Gestão Industrial. Instituto Superior Técnico (Lisboa).

Coelli, T., 1995. Estimators and hypothesis tests for a stochastic frontier function: A monte carlo analysis. The Journal of Productivity Analysis, 6, 247-268.

Cohen B., 2014. Portugal's anti-port. THIRSTY EXPLORER. Food \& Drink, Portugal. Available from (http:/www.bbc.com/travel/feature/20140708-vinho-verdeportugals-anti-port)

COM, 2012. Relatório da Comissão ao Parlamento Europeu e ao Conselho: em conformidade com o artigo $184^{\circ}, n^{\circ} 8$, do Regulamento (CE) $n .^{\circ}$ 1234/2007 sobre a experiência adquirida com a implementação da reforma do setor vitivinícola, de 2008. Comissão Europeia, Bruxelas.

Cullinane K., Song D.-W., 2006. Estimating the relative efficiency of European container ports: A Stochastic Frontier Analysis. Research in Transportation Economics, 16(1), 85-115.

Dean D.L., Mengüç B., Myers C.P., 2000. Revisiting firm characteristics, strategy, and export performance relationship: a survey of the literature and an investigation of New Zealand small manufacturing firms. Industrial Marketing Management, 29, 461477.

Edwards L., Alves P., 2006. South Africa's export performance: determinants of export supply. South African Journal of Economics, 74(3), 473-500.

European Central Bank / Eurosystem, 2013. Exchange rates. Available from http://sdw.ecb.europa.eu/browse.do?node=2018794

Fischer C., Gil-Alana L.A., 2009. The nature of the relationship between international tourism and international trade: the case of German imports of Spanish wine. Applied Economics, 41, 13451359

Grosso G., Marventano S., Giorgianni G., Raciti T., Galvano F., Mistretta A., 2014. Mediterranean diet adherence rates in Sicily, southern Italy. Public Health Nutrition, 17(9), 2001-2009.

Gwynne R.N., 2006. Export-orientation and enterprise development: a comparison of New Zealand and Chilean wine production. Tijdschrift voor Economische en Sociale Geografie, 97(2), 138-156.

International Organization of Vine and Wine (2013); Portuguese Export Market shares in the specific country's market. available from http://www.oiv.int/oiv/info/enstatoivextracts2?lang=en

IVV, 2012. Séries dos valores de exportação de vinho a partir de Portugal; available from http://www.ivv.min-agricultura.pt/np4/37

IVV (Consulted in 2014). A vinha e o vinho em Portugal. Available from http://www.ivv.min-agricultura.pt/np4/91.html
IVV, (s.d.). Análise de mercados de exportação: EUA - Canadá Brasil - Angola. Observatório do vinho. Available from (http://www.ivv.min-

agricultura.pt/np4/?newsId=1364\&fileName=Observatorio_Vinho. pdf).

Jongwanich J., 2010. Determinants of export performance in East and Southeast Asia. The World Economy, 33(1), 20-41.

Karelakis C., Mattas K., Chryssochoidis G., 2008. Greek wine firms: determinants of export performance. Agribusiness, 24(2), 275-297.

Kollmeyer C., 2015. Globalization and income inequality: How public sector spending moderates this relationship in affluent countries. International Journal of Comparative Sociology, 56(1), $3-28$.

Lu V.N., Quester P.G., Medlin C.J., Scholz B., 2012. Determinants of export success in professional business services: a qualitative study. The Service Industries Journal, 32(10), 1637-1652.

Maietta O.W., Sena V., 2010. Financial constraints and technical efficiency: some empirical evidence for Italian producers' cooperatives. Annals of Public and Cooperative Economics, 81(1), 21-38.

Observatório dos Mercados Agrícolas e das Importações AgroAlimentares (s.d.). Evolução da Balança de Pagamentos do Sector do Vinho entre 2000 e 2008. Available from (http://www.observatorioagricola.pt/rubricas/Balan\%C3\%A7aVinh o.pdf).

Olson, J.A., Schmidt, P., Waldman, D.M., 1980. A monte carlo study of estimators of stochastic frontier production functions. Journal of Econometrics, 13, 67-82.

Seo H.-J., Lee Y.S., Kim H., 2012. The determinants of export market performance in Organisation for Economic Co-operation and Development service industries. The Service Industries Journal, 32(8), 1343-1354.

Sousa, C.M.P., Martínez-López, F.J., Coelho, F., 2008. The determinants of export performance: A review of the research in the literature between 1998 and 2005. International Journal of Management Reviews, 10(4), 343-374.

Trotta, A.; Massaglia, S.; Ballotta, S.; Palma, S.; Bailet, I.; Liu, C. (2015). Interpretation keys in the process of sensitization and education of the Chinese consumer as to the consumption of wine. In: 38th World Congress of Vine and Wine (Part 1). Edited by: JeanMarie, A.. BIO Web of Conferences, Volume 5.

Viviani J.-L., 2009. Export implicit financial performance: the case of French wine companies. International Food and Agribusiness Management Review, 12(3), 23-48.

Wines of Portugal (Consulted in 2014). Regiões vitivinícolas Available from (http://www.winesofportugal.info/pagina.php?codNode=18012).

World Development Indicators (2012); available from http://data.worldbank.org/country/. 